\title{
Transanal minimal invasive surgery (TAMIS): safety and feasibility for the resection of benign and malignant lesions of the rectum
}

Asif Mehraj(D), Najmus Saqib(D), Rauf Wani(D), Nisar Chowdri(D), Fazl Parray(D), Mudassir Khan(D)

Department Colorectal Surgery, Sher-i-Kashmir Institute of Medical Sciences, Srinagar, India

\begin{abstract}
Objective: Radical surgery for rectal tumours has high morbidity. Local excision of such tumours can be achieved without compromising oncologic safety. However tumours that are not accessible to local excision can be approached using Transanal Minimal Invasive Surgery (TAMIS). The aim of our study was to assess feasibility of TAMIS procedure in terms of complications, operating time, resection margin positivity, hospital stay and local recurrence rate.

Material and Methods: Forty eight patients with benign adenomas or early stage adenocarcinoma, within 4 to $12 \mathrm{~cm}$ from anal verge who were subjected to TAMIS over a period of 3 years were included in the study. Short and long term outcomes were assessed.

Results: TAMIS was performed for 36 benign adenomas and 12 adenocarcinomas, which were located at an average distance of $6.2 \mathrm{~cm}$ from anal verge. The mean operating time was 72 minutes. There were no intraoperative complications.1 (2.08\%) patient suffered post operative bleeding, which was managed conservatively. 2 (4.16\%) patients developed acute urinary retention who required indwelling catheterisation. Resection margin was positive in $3(6.25 \%)$ benign cases. Average hospital stay was 2.7 days. Local recurrence occurred in 2 (4.16\%) villous adenoma patients (after 11 and 13 months), whereas in malignant patients there was no recurrence at a follow up period ranging between 12 to 36 months.
\end{abstract}

Conclusion: TAMIS is a safe and feasible procedure for benign tumours and early rectal cancers, located in low and middle rectum.

Keywords: Tamis, tubulovillous adenoma, early rectal cancer

Cite this article as: Mehraj A, Saqib N, Wani R, Chowdri N, Parray F, Khan M. Transanal minimal invasive surgery (TAMIS) safety and feasibility for the resection of benign and malignant lesions of the rectum. Turk J Surg 2021; 37 (1): 6-12.

\section{Corresponding Author}

Asif Mehraj

E-mail: asifdr80@yahoo.co.in

Received: 23.11.2020

Accepted: 27.01.2021

Available Online Date: 22.03 .2021

o Copyright 2021 by Turkish Surgical Society Available online at www.turkjsurg.com

DOI: $10.47717 /$ turkjsurg.2021.5057

\section{INTRODUCTION}

Radical surgery for rectal tumours has high morbidity. Local excision of such tumours can be achieved without compromising oncologic safety. However, tumours that are not accessible to traditional local excision or endoscopic resection can be approached using either Transanal Endoscopic Microsurgery (TEMS) or Transanal Minimal Invasive Surgery (TAMIS).

TEMS is superior to conventional Transanal excision with regard to completeness of excision $(1,2)$, but its equipment is costly and not available in many centres especially in developing nations with limited resources. Therefore, despite being in use for more than two decades, it has not been adopted by many colorectal surgeons across the globe.

TAMIS, on the other hand, has the advantage of being done using conventional laparoscopic instruments. Since its first description in 2010 by Sam Atallah et al. (3), who reported this technique safe and effective for resection of adenomas and early rectal cancers, TAMIS procedure has gained popularity among more and more surgeons all over the world. Besides the conventional laparoscopic instruments, a special port for inserting these instruments through the anal opening is required, which is available as Single Incision Laparoscopic surgery (SILS ${ }^{\text {TM }}$ port, Covidien, Mansfield, MA, USA), Single Site ${ }^{\mathrm{TM}}$ (SSL) device (Ethicon, Cincinnati, OH) and specifically designed for TAMIS, Gelpoint Path ${ }^{\mathrm{TM}}$ (Applied Medical, Rancho Santa Margarita, (A). 


\section{Aims and Objectives}

The primary outcome of our study was to assess the feasibility of TAMIS procedure in terms of operating time, intraoperative and postoperative complications, resection margin positivity, hospital stay, and local recurrence rate.

\section{MATERIAL and METHODS}

This was a prospective study carried in the Department of Colorectal Surgery at Sher I Kashmir Institute of Medical Sciences, Srinagar for a period of 3 years. All patients with a preoperative diagnosis of benign adenoma or early-stage adenocarcinoma ( $\mathrm{T} 1, \mathrm{NO}, \mathrm{M} 0$ ) within $12 \mathrm{~cm}$ from the anal verge were included in the study. Besides, one patient with multiple comorbidities with low performance status who was bleeding actively per rectum and had a T3NOMO lesion was also subjected to resection using TAMIS procedure. Preoperative staging in cases of adeno carcinoma was done using Magnetic resonance imaging (MRI) for the pelvis and Contrast enhanced computed tomography (CECT) for the abdomen and chest. Complete colonoscopy was done routinely to rule out any synchronous lesions. Full bowel preparation was used in majority of the patients one night prior to surgery, except a few (not suitable or refused) who received rectal enema on the evening preceding and on the morning of the day of surgery. Surgery was performed under general anaesthesia in all patients. Patients were kept in modified lithotomy or jack knife prone position depending on the site of lesion. Initially, we used SILS ${ }^{T M}$ port for transanal access in 14 patients and later shifted to Gelpoint Path ${ }^{\mathrm{TM}}$ in others (Figure 1). Gel port gives a better manoeuvrability for instruments as compared to SILS port. Pneumo rectum was created using $\mathrm{CO}_{2}$, which was set at a pressure of 15 to $18 \mathrm{~mm} \mathrm{Hg}$. Since there was no smoke removing apparatus (Air sea ${ }^{\oplus}$ ) available, an extra knob available on the gel port was opened to get rid of the excess smoke as and when needed. Most of the patients were operated in lithotomy position, though there was slight difficulty in operating lesions in the upper half, but were managed as such; however, 3 patients,

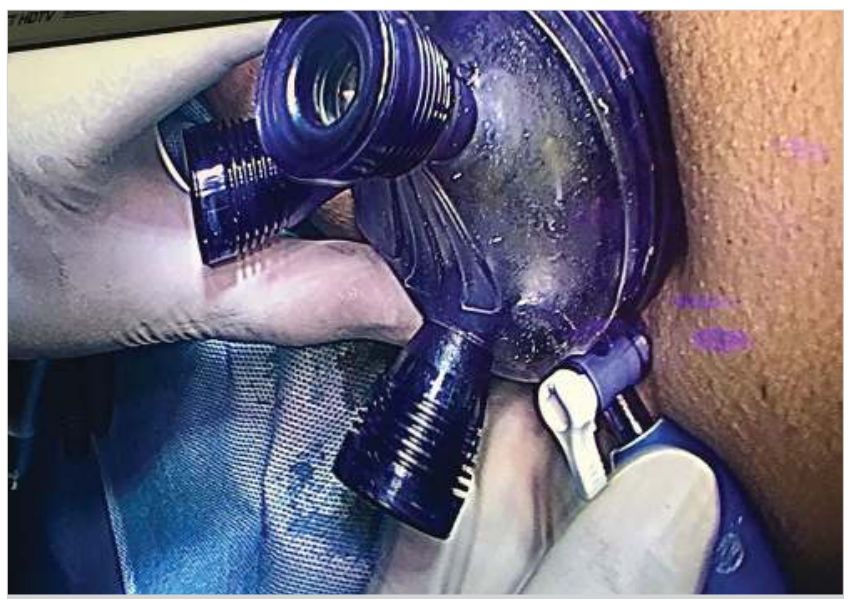

Figure 1. Gel point path port along with three trocars.

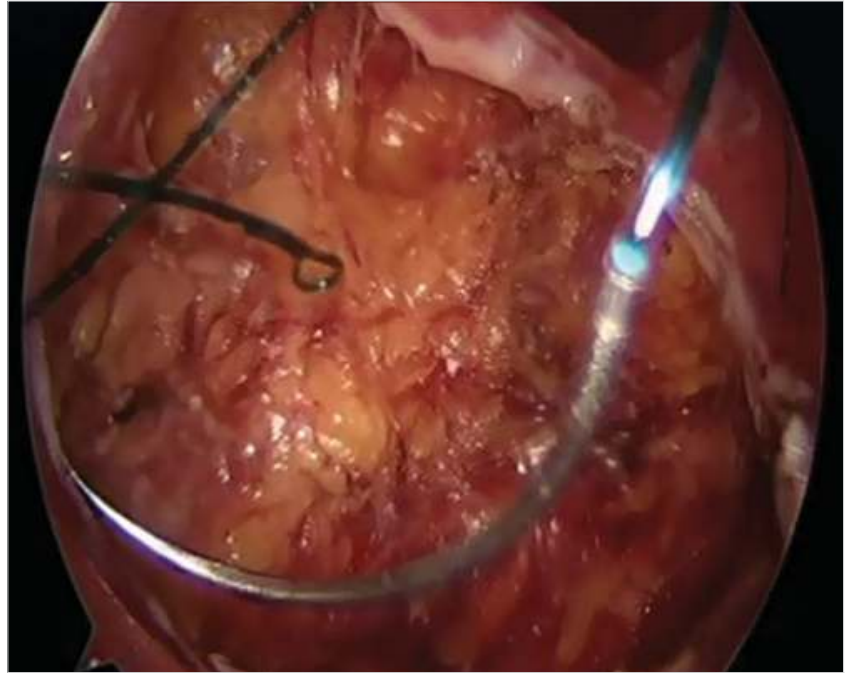

Figure 2. Suturing the rectal defect.

in whom the location was at 11 (in 2 patients) and 1 o'clock position, were operated in prone jack knife position. There are certain difficulties one may encounter during the procedure because of large size of the lesion, high up lesions and anatomical location of the lesion in the upper half of the operating field. Standard laparoscopic instruments were used. Resection of the lesion was done using mono polar electro cautery and harmonic scalpel. Full thickness excision was done in all cases with an aim to achieve $1 \mathrm{~cm}$ clear margin. The resultant defect was closed using $V$ Lock ${ }^{\mathrm{TM}}$ (Covidien) 3-0 absorbable suture on $26 \mathrm{~mm}$ needle in continuous fashion (Figure 2) without changing the pressure $(15-18 \mathrm{~mm} \mathrm{Hg})$. Light pack was kept in the rectum. Resected specimen was properly labelled and sent for histopathological examination. Light diet was started in the evening and followed by soft diet the next morning. The patients were regularly examined for any sign of bleeding. After discharge from hospital, the patients were again seen at two weeks and one month postoperatively and thereafter, in every 3 months. At every 3-month follow up, a proper digital rectal examination and proctoscopy were done to detect any local recurrence. Colonoscopy was done yearly. Follow up period ranged from 12-36 months.

\section{RESULTS}

A total of forty-eight patients underwent TAMIS procedure. Mean age of the patients was 51.07 years (25-72 years). Average size was $3.9 \mathrm{~cm}(1.2-8 \mathrm{~cm})$. Average distance from anal verge was $6.2 \mathrm{~cm}(4-12 \mathrm{~cm})$. Mean operating time was $72 \mathrm{~min}$ (46-110 min). There were no intra operative complications. Postoperatively, 1 patient developed bleeding per rectum on the evening of surgery and required one unit of packed red blood cells. However, bleeding stopped after conservative management. Two patients developed acute urinary retention following surgery which was managed by indwelling the catheter. One patient developed peritonitis following TAMIS for recurrent villous adenoma. This 
Table 1. Characteristics of malignant patients

\begin{tabular}{|c|c|c|c|c|c|c|c|}
\hline Patients No & Age/Sex & Pre-op Bx & Post-op Bx & LVI & PNI & Staging & Post-op Rx \\
\hline 3 & $72 / \mathrm{F}$ & WDA & WDA & + & + & T3NOMO & APR \\
\hline 7 & $38 / \mathrm{M}$ & VALGD & WDA & - & - & T1N0M0 & $F / U$ \\
\hline 9 & $63 / F$ & WDA & WDA & + & + & T2NOMO & TATA \\
\hline 14 & 70/M & WDA & WDA & + & + & T1N0M0 & ACRT \\
\hline 15 & $68 / M$ & WDA & WDA & - & - & T1N0MO & $F / U$ \\
\hline 19 & $66 / M$ & WDA & WDA & + & + & T1N0M0 & ACRT \\
\hline 20 & $24 / \mathrm{M}$ & VAHGD & WDA & - & - & T1NOMO & $F / U$ \\
\hline 23 & $50 / \mathrm{M}$ & VAHGD & WDA & + & - & T2NOMO & ULAR \\
\hline 34 & $55 / F$ & WDA & WDA & - & - & T1NOMO & $\mathrm{F} / \mathrm{U}$ \\
\hline 37 & $53 / \mathrm{M}$ & WDA & WDA & - & - & T2NOMO & TATA \\
\hline 42 & $65 / M$ & WDA & WDA & + & - & T1NOMO & ACRT \\
\hline 45 & $69 / M$ & WDA & WDA & - & - & T1N0M0 & $F / U$ \\
\hline
\end{tabular}

patient was initially subjected to low anterior resection for a huge tubulovillous adenoma at another institute. There was no fragmentation in any of the excised specimens. Mean hospital stay was 2.7 days (2-9 days).

Preoperative biopsy was villous adenoma in 39 (81.25\%) patients and well differentiated adenocarcinoma in 9 (18.75\%). However, postoperative biopsy revealed villous adenoma in 36 (75\%) and well differentiated adenocarcinoma in 12 (25\%) patients.

Out of twelve adenocarcinoma patients (Table 1), 3 had T1 tumour with lympho vascular and perineural invasion and were subjected to adjuvant chemo radiotherapy with 45 Gy of radiation over 25 cycles along with oral capecatabine. Three out of 12 adenocarcinoma patients had muscle invasion (T2) on the postoperative biopsy of the resected specimen. All 3 patients underwent Salvage surgery in the form of Transanal abdominal Transanal resection (TATA) in 2 \& Ultra low anterior resection (ULAR) in 1. Another patient had a locally advanced lesion (T3N1M0) and was having multiple comorbidities, had advanced age, and was bleeding actively. We took her for TAMIS as a palliative procedure. Postoperative biopsy revealed positive resection margin, and she underwent APR at other institute which was followed by a complicated postoperative course requiring ICU admission and massive blood transfusion. The remaining 5 patients with $\mathrm{T} 1$ lesion without any lymphovascular, perineural invasion and well differentiated adenocarcinoma on postoperative histology report are on regular follow up. None of the patients with adenocarcinoma developed local recurrence till date.

Out of the thirty-six villous adenomas, resection margin was positive in 3 patients, and 2 out of these 3 patients had large lesions occupying almost 75 and 80\% of circumference, respectively. Both of them were operated in two separate sessions, with an interval of 8 weeks between the sessions. Third patient had microscopic positive resection margin. She is on regular follow up for the last 14 months without any evidence of local recurrence. Other patients are recurrence free at follow up ranging from 12 months to 36 months. Two patients developed local recurrence, one after 11 months and the other after 13 months of initial surgery. First patient had a recurrence at the same site as the previous surgery and it was excised by redo TAMIS and postoperative biopsy revealed villous adenoma. In the other patient, there were two polyps at a separate site which were managed endoscopically with excision biopsy. There was no mortality in our series. Complications encountered during the series are tabulated in Table 2.

\section{DISCUSSION}

The concept of local excision of rectal neoplasia evolved long back in 1826 by Jacques Lisfranc (4). Subsequently, the technique was modified by Parks (5), which is still being practiced by most of the colorectal surgeons across the world. However, since the introduction of TEMS into clinical practice (6), it has progressively become the standard for treatment of benign polyps and early neoplasm $(7,8)$ and is associated with fewer surgery-associated morbidities an improved postoperative anorectal function, and a shortened postoperative recovery when compared with open or laparoscopic rectal resections $(9,10)$.

However, TEMS procedure has not gained widespread acceptability among surgeons because of high instrumentation cost and steep learning curve.

TAMIS, as a procedure, is more appealing for the surgeons because of the familiarity of the laparoscopic technique and in- 
Table 2. Complications

\begin{tabular}{|c|c|c|c|c|}
\hline Age/Sex & Pre-op Path & Post-op Path & Complications & Intervention \\
\hline 68/M & VAHGD & VAHGD & BLEEDING & Blood transfusion \\
\hline 70/M & WDA & WDA & AUR & Indwelling catheterisation \\
\hline $66 / \mathrm{M}$ & WDA & WDA & AUR & Indwelling catheterisation \\
\hline 73/M & VAHGD & VAHGD & Leak/peritonitis & Peritoneal mopping with ileostomy \\
\hline $72 / F$ & WDA & WDA & Advanced Stage & Salvage APR \\
\hline $63 / F$ & WDA & WDA & Muscle Invasion (T2) & Salvage TATA Resection \\
\hline 50/M & WDA & WDA & Muscle Invasion (T2) & Salvage ULAR \\
\hline $53 / \mathrm{M}$ & WDA & WDA & Muscle Invasion (T2) & Salvage TATA Resection \\
\hline $63 / F$ & VALGD & VALGD & Microscopic positive resection margin & Continuous follow up for 14 months; no recurrence \\
\hline $50 / F$ & VAHGD & VAHGD & Local Recurrence after 13 months & Endoscopic excision \\
\hline 48/M & VAHGD & VAHGD & Local Recurrence after 11 months & Redo TAMIS \\
\hline
\end{tabular}

M: Male, F: Female, Pre-op path: Preoperative pathology, Post-op path: Post operative pathology, WDA: Well differentiated adenocarcinoma, VALGD: Villous adenoma with low grade dysplasia, VAHGD: Villous adenoma with high grade dysplasia, AUR: Acute urinary retention, T: Tumour, APR: Abdominoperineal resection, TATA: Transanal trans abdominal procedure, ULAR: Ultra low anterior resection, TAMIS: Transanal minimal invasive surgery.

Table 3. Comparison of various studies

\begin{tabular}{|c|c|c|c|c|c|c|c|c|c|}
\hline Study & Country/Year & No. of pts & $\begin{array}{c}\text { Diameter } \\
(\mathrm{cm})\end{array}$ & $\begin{array}{l}\text { DAV } \\
(\mathrm{cm})\end{array}$ & $\begin{array}{l}\text { Op Time } \\
\text { (min) }\end{array}$ & $\begin{array}{c}\text { Hosp stay } \\
\text { (days) }\end{array}$ & $\begin{array}{c}\text { Morbidity } \\
(\%)\end{array}$ & $\begin{array}{c}\text { Mortality } \\
(\%)\end{array}$ & $\begin{array}{c}\text { Negative } \\
\text { margin (\%) }\end{array}$ \\
\hline Haugvik et al. & Norway 2016 & 51 & 3.2 & 8 & 40 & 1 & 12 & 0 & 47 \\
\hline Keller et al. & USA 2016 & 75 & 3.2 & 10 & 69 & 1 & 5.30 & 0 & NA \\
\hline Sumrien et al. & UK 2016 & 28 & 5 & NA & $<60$ & 1.5 & 29 & 0 & 82 \\
\hline Verseveld et al. & Netherland 2016 & 24 & 6 & $8 \Delta$ & NA & NA & 4 & 0 & NA \\
\hline A. Caycedo Marulanda et al. & Canada 2017 & 50 & 2.5 & 7 & 73 & 1.1 & 16 & 0 & 84 \\
\hline Nan Chen et al. & China 2018 & 25 & 1.1 & 8.4 & 61.3 & 2.7 & & 0 & 80 \\
\hline Present study & India & 48 & 3.9 & 6.2 & 72 & 2.7 & 8.33 & 0 & 93.75 \\
\hline
\end{tabular}

struments. One more advantage of TAMIS is that the position of the patient does not depend on the location of the tumour, as we can use an angled scope to visualise throughout the circumference of the rectum. However, it may initially be difficult for a surgeon to operate in the upper half (9-3 o'clock position) because of ergonomics. Nevertheless, with increasing experience, most of the tumours can be managed in modified lithotomy positions. We used modified lithotomy position in majority of the cases except for 3 patients in whom tumour location was between 11 and 1 o'clock position and were done in prone jack knife position. TAMIS is a feasible option for the treatment of rectal tumours and does not impair quality of life postoperatively (11). In our study, initial preoperative biopsy revealed benign disease in 39 patients and adenocarcinoma in 9 patients, but postoperative biopsy detected malignancy in 12 patients. In their series of 32 patients who underwent TAMIS procedure, Ana I Encinas-Muñiz et al. (12) have reported that 4 carcinomas were understaged (33.3\%) and 1 adenoma overstaged (6.7\%) preoperatively. There were also 3 (25\%) carcinomas which were not suspected preoperatively. This assumes importance in the management of colorectal polyps in that preoperatively labelled benign polyps can harbour foci of adenocarcinoma, so one should be vigilant while treating such cases.

In a systemic review by Martinez et al. (13), overall complications following the TAMIS procedure has been found as $7.4 \%$. The conversion rate in 390 cases performed for both benign and malignant lesions was $2.3 \%$. In malignant polyps, the rate of positive margins was $4.4 \%$ and the rate of tumor fragmentation was $4.1 \%$. Inadvertent peritoneal entry during TAMIS was reported in $1 \%$ of the cases. We encountered one anastomotic site leak in a patient who had undergone low anterior resection for a large tubulovillous adenoma at some other institute. There was a $4 \times 3 \mathrm{~cm}$ lesion at a previous anastomotic site. We performed TAMIS and excised the lesion with negative margins and closed the defect using $V$ Loc $^{\text {TM }}$ continuous suture. However, on the $3^{\text {rd }}$ postoperative day, the patient showed signs of 
peritonitis, and digital rectal examination showed a small defect at the closure site and was confirmed by a rectal dye test (water soluble). Patient was taken for exploratory laparotomy. Feculent material was seen in the peritoneal cavity. Thorough peritoneal lavage was done, and loop ileostomy was created for diversion. This complication can be attributed to the fact that in patients subjected to low anterior resection, peritoneum is divided and pelvic cavity is continuous with the peritoneal cavity, resulting in a generalised peritonitis instead of an otherwise localised pelvic collection. So, we suggest a prophylactic diverting stoma in such patients.

There is no debate over the closure of the rectal defect following excision of rectal neoplasm after TAMIS above the peritoneal reflection; however, there is lack of consensus when the excision is carried out below the reflection. In a recent meta-analysis of 555 patients who underwent excision of the rectal neoplasm by TEMS or TAMIS, 283 had their rectal defects sutured, while as in other 272, it was left open. Closing the defect resulted in significantly decreased rate of post-operative bleeding as compared to leaving the defect open. However, there was no statistical difference in postoperative infection, operative time and length of hospital stay between the two groups (14). In our series, we routinely closed all the defects.

In a recent study, Lee Lawrence et al. have reported a series of 200 elective TAMIS local excision procedures performed in 196 patients for 90 benign and 110 malignant lesions. Overall, a $7 \%$ margin positivity and 5\% fragmentation rate were observed. Mean operative time for TAMIS was 69.5 minutes. Postoperative morbidity was recorded in $11 \%$ of the patients, with hemorrhage (9\%), urinary retention (4\%), and scrotal or subcutaneous emphysema (3\%) being the most common. Mean follow up was 14.4 months. Local recurrence occurred in $6 \%$, and distant organ metastasis was noted in $2 \%$. Mean time to local recurrence for malignancy was 16.9 months (SD 13.2). Cumulative DFS for patients with rectal adenocarcinoma was $96 \%, 93 \%$, and $84 \%$ at 1,2 and 3 -years (15).

In another study from Europe, using TAMIS procedure for 75 patients, overall morbidity has been reported as 20\%. Five patients experienced postoperative bleeding, one of whom required tamponade with gauze, two were given blood transfusion (Grade II) and two required no special treatment (Grade I). Local infectious complications were seen in six (8\%) patients. One (1.3\%) patient was re-operated (TME, Grade IIIb) and five were treated with antibiotics (Grade II) (16).

In our study, there was no intraoperative complication. There was no tumour fragmentation during excision with all lesions removed intact. Overall, 4 (8.33\%) patients developed postoperative complications. One patient developed a leak requiring ileostomy, and the other 3 (6.25\%) patients developed minor postoperative complications in the form of acute urinary reten- tion in 2 patients and minor bleeding in 1 patient, all managed conservatively. There was no procedure-related mortality in our study. Resection margin was positive in 3 patients with tubulovillous adenoma. No patients with adenocarcinoma had a positive resection margin. Among these, 2 patients had huge lesions which were done in 2 sittings, and positive margins were present during the $1^{\text {st }}$ session. After excising the remaining lesion in the $2^{\text {nd }}$ session, resection margins were negative. In the $3^{\text {rd }}$ patient, resection margin was microscopically involved; however, the patient preferred to be on meticulous follow up instead of redo surgery and does not have any evidence of local recurrence till date for the last 14 months.

In cases of early rectal cancer, the rate of local recurrence is relatively high after local excision alone (17-19). However, the addition of adjuvant chemo radiotherapy after local excision significantly decreases the rate of local recurrence $(20,21)$. Toshiyuki Suzuki from Japan has reported their experience of 65 patients with clinical T1NOMO rectal cancer who were subjected to local excision followed by adjuvant chemo radiotherapy. Local recurrence occurred in 1 (2\%) and distant metastases in 3 patients (6\%) at a median follow up of 71 months. They have concluded that multidisciplinary treatment with local excision followed by chemo radiotherapy can be used as a treatment option in selected patients with clinical T1 NOMO rectal cancer (22). In patients with high-risk (tumour size $\geq 3 \mathrm{~cm}$, resection margin $\leq 3$ $\mathrm{mm}$, lymphovascular invasion, tumour resection by endoscopic mucosal resection or endoscopic sub mucosal dissection) pT1 rectal cancer, adjuvant chemo radiotherapy after local excision could be an effective alternative treatment instead of salvage radical resection. However, patients with pT2 stage have inferior oncological outcomes and should be subjected to completion total mesorectal excision (23). In a recent meta-analysis, Van Oostendorp et al. have evaluated oncological outcomes in 4674 patients of early rectal cancer (pT1-2) who were subjected to local excision followed by either no additional treatment, completion total mesorectal excision or adjuvant chemo radiotherapy. The study has revealed that patients who undergo no additional treatment have a high risk of local recurrence, especially those with high-risk PT1 and pT2 lesions. For high-risk PT1 tumours, the risk of local recurrence after adjuvant chemo radiotherapy is similar to that for completion total mesorectal excision. For pT2 tumours, adjuvant chemo radiotherapy seems less effective than radical surgery (24).

We had twelve adenocarcinoma patients in our series. Three patients with PT1 stage were subjected to adjuvant chemo radiotherapy. The other 3 patients had pT2 disease and underwent completion total mesorectal excision. Five patients had PT1 disease with no high-risk pathological factors and did not undergo any further treatment. One patient had a locally advanced rectal cancer who presented to us with massive tumour bleed. She underwent palliative resection of the tumour in view 
of her multiple comorbidities for the control of bleeding. Later on, she underwent abdominoperineal resection at some other hospital. No recurrence was reported among these patients at follow up ranging from 12-36 months.

Local recurrences following transanal excision is one of the biggest limitations of the procedure because of the constraints of proper space, which has ultimately led to the development of newer procedures like TEMS and TAMIS. In cases of benign diseases, local recurrence rates range from 4 to $10.3 \%$. $(14,25,26)$. In our study, local recurrence occurred in 2 (8.33\%) patients at 11 and 13 months respectively following primary surgery. Follow up period ranges from 12 to 36 months. In the first patient, recurrence occurred at a previously operated site, while in the other patient, there were 2 small lesions at a different location as compared to previous operated site. In the first case, redo TAMIS was done and pathology revealed tubulovillous adenoma and the other patient was managed with endoscopic removal of the tumour. To our knowledge, this is the first reported series of TAMIS from subcontinent, and our outcomes (Table 3) are consistent with most of the studies carried out worldwide (27-32).

\section{CONCLUSION}

TAMIS is a safe and feasible surgical technique used for the excision of both benign and early malignant lesions that are not accessible to conventional transanal or endoscopic resection. Short and midterm complications are within acceptable limits. It is a cost effective as well as a technically simpler procedure compared to TEMS. TAMIS can be used for resecting larger benign lesions in multiple sittings. However, literature comparing TAMIS with radical resection for malignant rectal tumors is limited and needs to be studied more in the future.

\section{ACKNOWLEDGEMENTS}

Dr. Semra Demirli Atici for translating the abstract to Turkish Language.

Ethics Committee Approval: The approval for this study was obtained from Institutional Ethics Committee of Sher-i-Kashmir Institute of Medical Sciences, Srinagar (Decision no: 23/2015 Date: 29.06.2015).

Peer-review: Externally peer-reviewed.

Author Contributions: Concept - N.A.C., R.A.W., N.S., F.Q.P.; Design - N.S., N.A.C., R.A.W., F.Q.P.; Supervision -N.A.C., A.M., R.A.W.; F.Q.P.; Materials - N.A.C., R.A.W., F.Q.P., M.K.; Data Collection and/or Processing - A.M., N.S., M.K.; Analysis and Interpretation - A.M., N.S., M.K., R.A.W.; Literature Review - A.M., N.A.C., F.Q.P., R.A.W., N.S.; Writing Manuscript - A.M., R.A.W, N.A.C., M.K., N.S. Critical Reviews - A.M., F.Q.P., N.A.C., R.A.W.

Conflict of Interest: The authors declare that they have no conflict of interest.

Financial Disclosure: The authors declared that this study has received no financial support.

\section{REFERENCES}

1. Christoforidis D, Cho HM, Dixon MR. Transanal endoscopic microsurgery versus conventional trans anal excision for patients with early rectal cancer. Ann Surg 2009; 249: 776-82. [CrossRef]

2. e Graaf EJ, Burger JW, van ljsseldijk AL, Tetteroo GW, Dawson I, Hop WC. Transanal endoscopic microsurgery is superior to trans anal excision of rectal adenomas. Colorectal Dis 2011; 13: 762-7. [CrossRef]

3. Atallah S, Albert M, Larach S. Transanal minimally invasive surgery: a giant leap forward. Surg Endosc 2010; 24: 2200-5. [CrossRef]

4. Lisfranc J. Classic articles in colonic and rectal surgery. Jacques Lisfranc 1790-1847. Observation on a cancerous condition of the rectum treated by excision. Dis Colon Rectum 1983; 26: 694-5. [CrossRef]

5. Parks AG. A technique for excising extensive villous papillomatous change in the lower rectum. Proc R Soc Med 1968; 61:441-2. [CrossRef]

6. Buess G, Theiss R, Günther M, Hutterer F, Pichlmaier H. Endoscopic surgery in the rectum. Endoscopy 1985; 17: 31-5. [CrossRef]

7. Moore JS, Cataldo PA, Osler T, Hyman NH. Transanal endoscopic microsurgery is more effective than traditional trans anal excision for resection of rectal masses. Dis Colon Rectum 2008; 51: 1026-30. [CrossRef]

8. Casadesus D. Surgical resection of rectal adenoma: A rapid review. World J Gastroenterol 2009; 15: 3851-4. [CrossRef]

9. Bach SP, Hill J, Monson JR, Simson JN, Lane L, Merrie A, et al. Association of Coloproctology of Great Britain and Ireland Transanal Endoscopic Microsurgery (TEM) Collaboration: A predictive model for local recurrence after trans anal endoscopic microsurgery for rectal cancer. Br J Surg 2009; 96: 280-290. [CrossRef]

10. Doornebosch PG, Tollenaar RA, Gosselink MP, Stassen LP, Dijkhuis CM, Schouten WR, et al. Quality of life after trans anal endoscopic microsurgery and total mesorectal excision in early rectal cancer. Colorectal Dis 2007; 9: 553-8. [CrossRef]

11. Sumrien H, Dadnam C, Hewitt J, Mccarthy K. Feasiblity of transanal minimally invasive surgery (TAMIS) for rectal tumours and its impact on quality-of life the bristol series. Anticancer Research 2016; 36: 2005-10. [CrossRef]

12. Encinas-Muñiz Al, Sánchez-Domínguez L. Indications and Outcomes from 32 consecutive patients for the treatment of rectal lesions by transanal minimally invasive surgery. Surg Innov 2017; 24(4): 336-42. [CrossRef]

13. Martin-Perez B, Andrade-Ribeiro GD, Hunter L, Atallah S. A systematic review of trans anal minimally invasive surgery (TAMIS) from 2010 to 2013. Tech Coloproctol 2014; 18: 775-88. [CrossRef]

14. KKhan, IA Hunter, TManzoor. Should the rectal defect be sutured following TEMS/TAMIS carried out for neoplastic rectal lesions? A metaanalysis. Ann R Coll Surg Engl 2020; 102: 647-653. [CrossRef]

15. Lawrence L, Burke JP, deBeche-Adams T, Nassif G, Martin-Perez B, Monson JRT, et al. Transanal minimally invasive surgery for local excision of benign and malignant rectal neoplasia: outcomes from 200 consecutive cases with midterm follow up. Ann Surg 2018; 267: 910-6. [CrossRef]

16. Hahnloser D, Cantero R, Salgado G, Dindo D, Rega D, Delrio P. Transanal minimal invasive surgery for rectal lesions: Should the defect be closed? Colorectal Dis 2015; 17(5): 397-402. [CrossRef]

17. Stornes T, Wibe A, Nesbakken A, Myklebust TA, Endreseth BH. National early rectal cancer treatment revisited. Dis Colon Rectum 2016; 59:623-9. [CrossRef]

18. Patel SA, Chen YH, Hornick JL, Catalano P, Nowak JA, Zukerberg LR, et al. Early-stage rectal cancer: clinical and pathologic prognostic markers of time to local recurrence and overall survival after resection. Dis Colon Rectum 2014; 57: 449-59. [CrossRef] 
19. Ikematsu H, Yoda Y, Matsuda T, Yamaguchi Y, Hotta K, Kobayashi N, et al. Long-term outcomes after resection for submucosal invasive colorectal cancers. Gastroenterology 2013; 144:551-9. [CrossRef]

20. Sasaki T, Ito Y, Ohue M, Kanemitsu Y, Kobatake T, Ito M, et al. Postoperative chemoradiotherapy after local resection for high-risk T1 to T2 low rectal cancer: results of a single-arm, multi-institutional, phase Il clinical trial. Dis Colon Rectum 2017; 60: 914-21. [CrossRef]

21. Gonzalez QH, Heslin MJ, Shore G, Vickers SM, Urist MM, Bland KI. Results of long-term follow-up for transanal excision for rectal cancer. Am Surg 2003; 69: 675-8. [CrossRef]

22. Suzukia T, Sadahiroa S, Tanakaa A, Okadaa K, Saitoa G, Miyakitaa H, et al. outcomes of local excision plus chemoradiotherapy in patients with $T 1$ rectal cancer. Oncology 2018; 95: 246-50. [CrossRef]

23. Jeong JU, Nam TK, Kim HR, Shim HJ, Kim YH, Yoon MS, et al. Adjuvant chemoradiotherapy instead of revision radical resection after local excision for high-risk early rectal cancer. Radiat Oncol 2016; 11(1): 114 [CrossRef]

24. Van Oostendorp SE, Smits LH, Vroom Y, Detering R, Heymans MW, Moons $L M G$, et al. Local recurrence after local excision of early rectal cancer: a meta-analysis of completion TME, adjuvant (chemo)radiation, or no additional treatment. Br J Surg 2020; 107(13): 1719-30. [CrossRef]

25. Pigot F, Bouchard D, Mortaji M, Castinel A, Juguet F, Chaume JC, et al. Local excision of large rectal villous adenomas: long-term results. Dis Colon Rectum 2003; 46: 1345-50. [CrossRef]
26. Matthew A, Atallah S, deBeche-Adams TC, Izfar S, Larach SW. Transanal Minimally Invasive Surgery (TAMIS) for local excision of benign neoplasms and early-stage rectal cancer: efficacy and outcomes in the first 50 patients. Dis Colon Rectum 2013; 56(3): 301-7. [CrossRef]

27. García-Flórez L, Otero-Díez JL, Encinas-Muñiz Al, Sánchez-Domínguez L. Indications and outcomes from 32 consecutive patients for the treatment of rectal lesions by transanal minimally invasive surgery surgical innovations. 2017; 24(4): 336-42. [CrossRef]

28. Haugvik SP, Groven S, Bondi J, Vågan T, Brynhildsvoll SO, Olsen OC. A critical appraisal of trans anal minimally invasive surgery (TAMIS) in the treatment of rectal adenoma: a 4-year experience with 51 cases. Scand J Gastroenterol 2016; 51:855-9. [CrossRef]

29. Keller DS, Tahilramani RN, Flores-Gonzalez JR. Transanal minimally invasive surgery: review of indications and outcomes from 75 consecutive patients. J Am Coll Surg 2016;222:814-22. [CrossRef]

30. Verseveld M, Barendse RM, Gosselink MP, VerhoefC, de GraafEJR, Doornebosch PG. Transanal minimally invasive surgery: impact on quality of life and functional outcome. Surg Endosc 2016; 30: 1184-7. [CrossRef]

31. Caycedo-Marulanda A, Jiang HY, Kohtakangas EL. Transanal minimally invasive surgery for benign large rectal polyps and early malignant rectal cancers: experience and outcomes from the first Canadian centre to adopt the technique. Can J Surg 2017; 60(6): 416-23. [CrossRef]

32. Chen N, Peng Y-F, Yao Y-F, Gu J. Trans-anal minimally invasive surgery for rectal neoplasia: Experience from single tertiary institution in China World. World J Gastrointest Oncol 2018; 10(6): 137-44. [CrossRef]

\section{ORIJINAL ÇALIŞMA-ÖZET}

Turk J Surg 2021; 37 (1): 6-12

\section{Transanal minimal invaziv cerrahi (TAMIS): benign ve malign rektum lezyonlarının rezeksiyonunda güvenilirliği ve uygulanabilirliği}

Asif Mehraj, Najmus Saqib, Rauf Wani, Nisar Chowdri, Fazl Parray, Mudassir Khan

Sher-i-Kashmir Tıbbi Bilimler Enstitüsü, Kolorektal Cerrahi Anabilim Dalı, Srinagar, Hindistan

\section{ÖZET}

Giriş ve Amaç: Rektal tümörler için radikal cerrahi yüksek morbiditeye sahiptir. Onkolojik güvenlikten ödün vermeden bu tümörlerin lokal eksizyonu gerçekleştirilebilir. Ancak lokal eksizyonla erişilemeyen tümörlere transanal minimal invaziv cerrahi (TAMIS) uygulanarak ulaşılabilir. Çaıışmamızın amacı TAMIS prosedürünün uygulanabilirliğini komplikasyonlar, ameliyat süresi, rezeksiyon sınır pozitifliği, hastanede kalış süresi ve lokal nüks oranı açısından değerlendirmektir.

Gereç ve Yöntem: Çalışmaya 3 yıllık bir süre boyunca TAMIS uygulanan, anal verge'den 4-12 cm uzaklıkta, iyi huylu adenomu veya erken evre adenokarsinomu olan kırk sekiz hasta dahil edildi. Kısa ve uzun vadeli sonuçlar değerlendirildi.

Bulgular: Anal verge'den ortalama 6,2 cm uzaklıkta bulunan 36 iyi huylu adenom ve 12 adenokarsinom için TAMIS uygulandı. Ortalama operasyon süresi 72 dakikaydı. Herhangi bir intraoperatif komplikasyon gözlenmedi. $1(\% 2,08)$ hastada postoperatif kanama görüldü, konservatif tedavi ile yönetildi. $2(\% 4,16)$ hastada kalıc kateterizasyon gerektiren akut idrar retansiyonu gelişti. İyi huylu üç $(\% 6,25)$ olguda rezeksiyon sınırı pozitifti. Ortalama hastanede kalış süresi 2,7 gündü. Takip süresi 2 ile 36 ay arasında değişiyordu. Lokal eksizyon yapılan $2(\% 4,16)$ villöz adenom hastasında (11 ve 13 ay sonra) lokal nüks meydana geldi.

Sonuç: TAMIS, alt ve orta rektumda yerleşmiş iyi huylu tümörler ve erken evre rektal kanserler için güvenli ve uygulanabilir bir prosedürdür.

Anahtar Kelimeler:TAMIS, tubulovillöz adenom, erken evre rektum kanseri

DOi: $10.47717 /$ turkjsurg.2021.5057 